\title{
Student satisfaction in e-learning along the COVID-19 pandemic with importance performance analysis
}

\author{
Lila Bismala', Yayuk Hayulina Manurung ${ }^{2}$ \\ ${ }^{1}$ Faculty of Economic and Business, University of Muhammadiyah Sumatera Utara, Medan, Indonesia \\ ${ }^{2}$ Faculty of Teacher Training and Education, University of Muhammadiyah Sumatera Utara, Medan, Indonesia
}

\section{Article Info \\ Article history: \\ Received Jan 13, 2021 \\ Revised Jun 8, 2021 \\ Accepted Jul 12, 2021}

\section{Keywords:}

E-learning

Independent learning process

Self-motivation

Student satisfaction

\begin{abstract}
The COVID-19 pandemic caused learning to be done with an online system, one of which is by using e-learning. The use of e-learning received a lot of reactions, both from the student and lecturer side. Lecturers should be able to make the best preparation, both in terms of materials, media, content, interaction and flexibility in the use of e-learning, so that students do not have difficulty in distance learning done. While students should prepare themselves as best as possible, both in terms of technology, ability, interaction with colleagues and lecturers, as well as motivation in conducting distance learning using e-learning. This study aimed to investigate student satisfaction in using e-learning as a method of distance learning during the COVID-19 pandemic, using Importance Performance Analysis (IPA). The number of respondents in this study was 132 students. The results showed that there are several factors that need to be improved, such as materials presented in e-learning, interaction with lecturers, availability of facilities, and lecturers. Factors that should be maintained included flexibility, assessment in e-learning that is felt to be appropriate, the benefits of elearning, and students' ability to allocate time. Meanwhile, factors that are considered less important and do not obtain priorities include peers, easy-tounderstand materials, ability to learn independently and understand tasks. In addition, students consider there are several factors that are considered too excessive, namely self-motivation, ability to understand the use of e-learning, independent learning process.
\end{abstract}

This is an open access article under the CC BY-SA license.

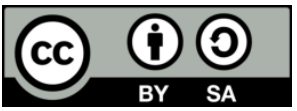

\section{Corresponding Author:}

Lila Bismala

Faculty of Economic and Business

University of Muhammadiyah Sumatera Utara

Jl. Kapten Mukhtar Basri No. 3, Medan, Indonesia

Email: lilabismala@umsu.ac.id

\section{INTRODUCTION}

The COVID-19 pandemic has changed the education system. Restriction of physical and social distance causes education that was initially done face-to-face or offline, to change to online. This online learning is done from the home of each student, where lecturers have provided a series of materials and structured tasks in various media that students can easily access, one of which is through the Learning Management System (LMS) or known as e-learning. In many colleges, lecturers are given the freedom to choose the LMS best suited to their needs, but this creates conflict for students, because, in the transition process, they find the need to use more virtual platforms, making them challenged to self-study [1].

Distance learning with e-learning provides many benefits for students, such as improved information accessibility, better content delivery, personalized instruction, content standardization, accountability, on- 
demand availability, speed, interactivity, confidence, and increased comfort [2], [3], while the weakness is the obligation of students to have a computer or other device to access e-learning, and reduce face-to-face with friends [3]. E-learning is self-learning where students engage in online tutorials to complete tasks given to them. The changing learning system demands the readiness of lecturers, students, and campuses to face this online learning. Online learning is not easy because there is no habituation, and the lack of face-to-face causes students to have difficulty understanding the material as a whole [3]. The difficulties experienced by students in e-learning cause their dissatisfaction with this learning system.

Self-learning plays an important role in both traditional and e-learning environments. The learning environment should provide some kind of expert assistance or guidance to make the information in the elearning environment more structured, provide more learning possibilities for students and help students solve disorientation problems [4]. This situation affects the quality of e-learning, which has an impact on the satisfaction of e-learning users. Service quality involves comparing expectations with performance. The quality of e-learning services is the mismatch between a student's experience and the services (materials including curriculum design, e-learning functions) offered by a particular institution and their expectations about the service. Quality has always been a major concern in the field of education and therefore various researches related to quality and education have been conducted around the world [5]. Satisfaction has a positive influence on motivation in e-learning. When students gain satisfaction from e-learning, they become highly motivated, leading to more intensive engagement with learning materials.

Satisfaction in using e-learning is influenced by the learning process [6]-[9], quality tutor [6]-[11], perception of usability [6], perception of convenience [9], facilitating conditions [8], [9], personalization of elearning [12], e-learning content [7], [8], [10], [12], e-learning self-efficacy [12]-[14], interaction (communication) [11], [15], [16], comfort [15], structure (clarity and online instruction provided by instructor) [15], learning style [15], platform [15], associates [7], [10], rating [10], student [10], [17], technology [8], [10], [16], [17], management [16]. A study conducted by Bhuasiri, et al. [2] found six dimensions for implementing e-learning systems in developing countries, including student characteristics, instructor characteristics, institution and service quality, infrastructure and system quality, course quality and information, and extrinsic motivation.

The design of effective e-learning courses should be developed taking into account student characteristics to produce better learning outcomes [18]. Dabbagh [19] mentions some characteristics and skills that are considered important for the success of e-learning, namely having a strong academic selfconcept, showing fluency in using online learning technology, having interpersonal and communication skills, understanding and appreciating collaborative interaction and learning, having an internal control lofly, showing self-learning skills, and showing the need to be affiliated. Meanwhile, Thanji and Vasantha [18] mentioned that some factors of online student success include time commitment, motivation and discipline, having technological skills, having reading skills and process understanding, sharing ideas and experiences, time management skills, having writing skills, reporting problems immediately, meeting learning qualifications, trusting online learning, the ability to apply critical thinking.

This research is important to do considering that e-learning is a relatively new learning system, and there are difficulties from students and lecturers to use it. This difficulty is due to independent learning patterns that students inevitably have to face, support from classmates, interaction and flexibility among colleagues and lecturers and other things that become obstacles in the implementation of e-learning. The results of this research will provide input in the implementation of effective e-learning, which is assessed from the perspective of students.

\section{RESEARCH METHOD}

This study aimed to measure student satisfaction in using e-learning, using Importance Performance Analysis (IPA). The use of IPA matrix is still not widely used in assessing the quality of learning, especially e-learning. This research employed descriptive quantitative analysis with Importance Performance Analysis (IPA). IPA is an easy-to-apply technique to measure importance and performance attributes, can develop effective marketing programs [20].

Presenting results on the performance-interest grid facilitates management's interpretation of data and improve its usefulness in making strategic marketing decisions [20]. The IPA is designed to compare average scores on the 'perceived importance' of various features with 'satisfaction ratings' that correspond to using a two-dimensional grid [20]-[23]. This grid will classify mean scores into four categories to aid data interpretation and assess priority management: 'maintain good work', 'concentration here', 'low priority', and 'excessive likelihood', allowing management to identify areas of highest concern that warrant limited use of funds [22]-[24]. 
The elements of student satisfaction studied in the use of e-learning include peers (2 questions) [9], [15], content design (2 questions) [9], [10], [12], [15], interaction and flexibility (4 questions) [16], [19], assessment (3 questions) [10], students (7 questions) [15], technology (2 questions) [15], [19], lecturers (3 questions) [6], [9], [12], [14], [16], and learning process (2 questions) [6], [9], [12], [14]. The quality of elearning was measured using survey methods by distributing questionnaires to students who attended Production Management courses, as many as 164 students of the Management Study Program at the University of Muhammadiyah Sumatera Utara, but the number of respondents who filled out the poll was 132 people. Data collection is done by distributing questionnaires using Google Forms. The instrument was developed with a total of 25 questions using a Likert scale of 5 alternative answers used in the performance assessment system (with a scale of five which includes: very satisfied (5), satisfied (4), dissatisfied (3), dissatisfied (2), very dissatisfied (1)) and a system of assessment of consumer expectations towards elearning (with a scale of five which includes: very important (5), important (4), less important (3), not important (2) and very unimportant (1)). Higher points indicate higher performance and expectations in the specified dimensions, while lower points indicate lower performance and expectations in the specified dimensions.

\section{RESULTS AND DISCUSSION}

The respondents consisted more women (65\%). Meanwhile, in terms of age, it was found that respondents aged mostly of 19 years as many as 86 people $(65 \%)$. While the domicile of respondents, half is in the city of Medan and half is outside the city of Medan. The calculation of student performance and importance in using e-learning is shown in Table 1. After obtaining the average performance and importance, then the next is plotting those values in a grid consisting of four quadrants (matrix performance analysis) as shown in Figure 1.

Table 1. Results of performance and importance calculation in using e-learning

\begin{tabular}{|c|c|c|c|c|}
\hline Instrument & $\begin{array}{l}\text { Performance } \\
\text { assessment } \\
\text { (X) }\end{array}$ & $\begin{array}{l}\text { Importance } \\
\text { assessment } \\
\text { (Y) }\end{array}$ & $\begin{array}{c}\text { Performance } \\
\text { average=performance } \\
\text { assessment/amount } \\
\text { of respondent }\end{array}$ & $\begin{array}{c}\text { Importance } \\
\text { average=importance } \\
\text { assessment/amount } \\
\text { of respondent }\end{array}$ \\
\hline 1. Peers assist in the implementation of e-learning & 465 & 554 & 3.52 & 4.20 \\
\hline $\begin{array}{l}\text { 2. Can discuss with peers interactively about the material } \\
\text { in e-learning }\end{array}$ & 429 & 547 & 3.25 & 4.14 \\
\hline $\begin{array}{l}\text { 3. Materials submitted in e-learning are easy to } \\
\text { understand }\end{array}$ & 431 & 545 & 3.27 & 4.13 \\
\hline $\begin{array}{l}\text { 4. The content and appearance of materials motivates to } \\
\text { learn }\end{array}$ & 452 & 558 & 3.42 & 4.23 \\
\hline 5. Interaction with lecturers in the e-learning process & 436 & 564 & 3.30 & 4.27 \\
\hline $\begin{array}{l}\text { 6. Interaction with lecturers about the material (not about } \\
\text { network difficulties, delays due to student error) }\end{array}$ & 445 & 560 & 3.37 & 4.24 \\
\hline $\begin{array}{l}\text { 7. The flexibility (tolerance of time) given in relation to } \\
\text { signals }\end{array}$ & 473 & 579 & 3.58 & 4.39 \\
\hline $\begin{array}{l}\text { 8. Flexibility is given when it comes to difficulty } \\
\text { understanding the material }\end{array}$ & 467 & 574 & 3.54 & 4.39 \\
\hline 9. Fair assessment in e-learning & 480 & 587 & 3.64 & 4.45 \\
\hline 10. Open assessments in e-learning & 476 & 570 & 3.61 & 4.32 \\
\hline 11. Assessments can be known after collecting tasks & 484 & 559 & 3,67 & 4.23 \\
\hline 12. Ability to learn independently with e-learning & 438 & 542 & 3.32 & 4.11 \\
\hline 13. High self-motivation despite self-study & 471 & 546 & 3.57 & 4.14 \\
\hline 14. With e-learning can learn anywhere and anytime & 527 & 559 & 3.99 & 4.23 \\
\hline 15. Ability to understand the use of e-learning & 483 & 550 & 3.66 & 4.17 \\
\hline 16. Ability to understand the instructions given & 469 & 547 & 3.55 & 4.14 \\
\hline $\begin{array}{l}\text { 17. Difficulty in operating e-learning, although including } \\
\text { students who are able to use social media }\end{array}$ & 470 & 514 & 3.56 & 3.89 \\
\hline $\begin{array}{l}\text { 18. Learning independently about the subject matter and } \\
\text { also learning how to use e-learning }\end{array}$ & 475 & 539 & 3.6 & 4.08 \\
\hline $\begin{array}{l}\text { 19. The presence of a dwelling makes it possible to } \\
\text { receive signals easily }\end{array}$ & 466 & 561 & 3.53 & 4.25 \\
\hline 20. Have a device to implement e-learning & 510 & 575 & 3.86 & 4.36 \\
\hline 21. Lecturers give clear instructions & 443 & 589 & 3.36 & 4.46 \\
\hline 22. Lecturers provide feedback on the material & 451 & 577 & 3.42 & 4.37 \\
\hline $\begin{array}{l}\text { 23. Lecturers do not want to be burdened with student } \\
\text { negligence in the collection of assignments }\end{array}$ & 444 & 506 & 3.36 & 3.83 \\
\hline 24. E-learning gives you freedom to learn anywhere & 539 & 563 & 4.08 & 4.27 \\
\hline
\end{tabular}


Table 1. Results of performance and importance calculation in using e-learning (continued)

\begin{tabular}{|c|c|c|c|c|}
\hline Instrument & $\begin{array}{l}\text { Performance } \\
\text { assessment } \\
\text { (X) }\end{array}$ & $\begin{array}{l}\text { Importance } \\
\text { assessment } \\
\text { (Y) }\end{array}$ & $\begin{array}{c}\text { Performance } \\
\text { average=performance } \\
\text { assessment/amount } \\
\text { of respondent }\end{array}$ & $\begin{array}{c}\text { Importance } \\
\text { average=importance } \\
\text { assessment/amount } \\
\text { of respondent }\end{array}$ \\
\hline 25. Ability to allocate special learning time for e-learning & 495 & 559 & 3.75 & 4.23 \\
\hline \multirow[t]{4}{*}{ Eaverage } & 2218 & 2065 & 88.78 & 105.48 \\
\hline & & & $\overline{X_{1}}=\underline{\sum_{i=1}^{n} \bar{X}_{i 1}}$ & $\overline{Y_{1}}=\underline{\sum_{i=1}^{n} \bar{Y}_{i 1}}$ \\
\hline & & & $\begin{array}{rl}\Lambda_{1}-r & k \\
-8878 & k 5\end{array}$ & $1-\frac{k}{-1054805}$ \\
\hline & & & $\begin{array}{l}=88.18 / 25 \\
=3.55\end{array}$ & $\begin{array}{l}=105.48 / 25 \\
=4.22\end{array}$ \\
\hline
\end{tabular}

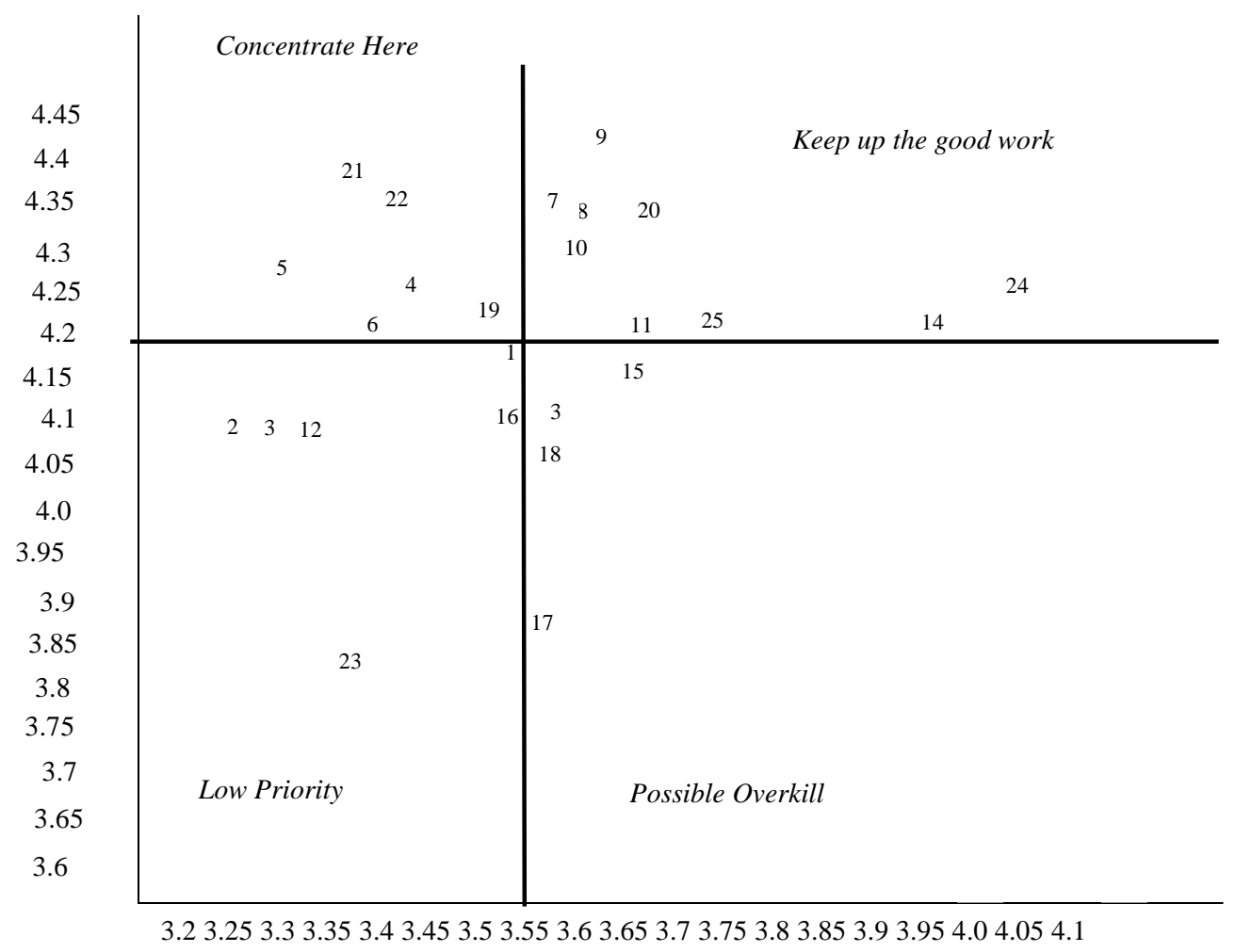

Figure 1. IPA quadrant (Important and performance analysis)

Based on the results of data processing, it can be seen the position of each instrument used in this research, in the IPA matrix. The positions of each instrument are:

a. Keep up the good work: (7) The flexibility (tolerance of time) given in relation to signals, (8) Flexibility is given when it comes to difficulty understanding the material, (9) Fair assessment in e-learning, (10) Open assessments in e-learning, (11) Assessments can be known after collecting tasks, (14) With elearning can learn anywhere and anytime, (20) Have a device to implement e-learning (24) E-learning gives you freedom to learn anywhere (25) Ability to allocate special learning time for e-learning,

b. Concentrate here: (4) The content and appearance of materials motivates to learn, (5) Interaction with lecturers in the e-learning process, (6 Interaction with lecturers about the material (not about network difficulties, delays due to student error), (19) The presence of a dwelling makes it possible to receive signals easily, (21) Lecturers give clear instructions (22) Lecturers provide feedback on the material

c. Low priority: (1) Peers assist in the implementation of e-learning, (2) Can discuss with peers interactively about the material in e-learning, (3) Materials submitted in e-learning are easy to understand, (12) Ability to learn independently with e-learning, (16) Ability to understand the instructions given, (23) Lecturers do not want to be burdened with student negligence in the collection of assignments

d. Possible overkill: (13) High self-motivation despite self-study, (15) ability to understand the use of elearning, (17) difficulty in operating e-learning, although including students who are able to use social media, (18) learning independently about the subject matter and also learning how to use e-learning 
In the IPA matrix, the Concentrate here quadrant, is a region containing factors that are considered important, but in reality, these factors have not been as expected (the level of satisfaction obtained is still low), so it must be improved. This means that in the use of e-learning, students want more intensive interaction with lecturers and materials that can be more motivating in learning. Lecturers should be able to adapt existing learning theories for the digital age, while using connectivism principles to guide the development of effective learning materials [25]. In addition, educational institutions need training for teachers on how to improve online learning, make good material, and make learning media more interactive [26]. What is needed is not a new stand-alone theory for the digital age, but a model that integrates various theories to guide the design of online learning materials. Online learning should include a variety of learning activities to help students achieve learning outcomes and to meet their individual needs [25]. Therefore, lecturers need to understand the application of software and the implications of technology in order to adopt the technology and improve the student learning experience [27]. It is further mentioned that lecturers should be able to design online learning that will make students more interested and interactive, and therefore, lecturers should use the right tools, not just those available. In addition, lecturers must play a social role to keep students motivated and improve their learning. Such skills and roles can be considered as obstacles that can prevent lecturers from utilizing e-learning, given the many efforts that must be put in place in order for the success and sustainability of e-learning to produce maximum results. Instructor quality, timeliness of instructor response, teaching style, and assistance to learners through the e-learning system as a benchmark for instructor quality. This means that student satisfaction with the e-learning system is positively affected when instructors respond to students in a timely manner, their teaching methods are effective, and they have control over technology [9].

Quadrant Keep up the good work is an area that contains factors that are considered important and factors that are considered to be in accordance with what it feels so that the level of satisfaction is relatively higher so that it must be maintained because all these variables make the product/service superior in consumer perception. In this quadrant, students consider that flexibility and assessment are satisfactory, elearning makes it easy to learn anywhere and anytime, and they already have the ability to allocate study time. E-learning technology offers learners control over content, learning order, learning speed, time, and often media, allowing them to tailor their experiences to meet their personal learning goals to manage access to e-learning materials, consensus on technical standardization, and methods for peer review of these resources [15]. Feedback is an important concept in education, learning and evaluation, so lecturers should be able to encourage students to identify success in the Learning process, and help bridge the gap between hope and reality [28].

The low priority quadrant is an area that contains factors that are considered less important and in fact the performance is not very special. The increase in variables included in this quadrant can be reconsidered because the effect on the benefits felt by customers is very small. Instruments included in this quadrant include interaction with peers, student abilities, easy-to-understand materials. Online learning, however, involves more than just presentation and delivery of materials using the Web. Students and the learning process should be the focus of online learning. There must be interaction between students and other students, participate in the process of cognition together, form social networks, and build a social presence. Learners should be able to interact in the context of them personalizing information and building their own meaning [25]. E-learning is based on the principle of socio-constructivism, where students can generate their knowledge through collaborative online learning through an online platform [29].

Quadrants possible overkill is an area that contains factors that are considered less important and perceived to be excessive. The variables included in this quadrant can be reduced to be able to save costs. The instruments included in this quadrant include students' abilities, both in terms of motivation and ability in the use of e-learning, and the process of self-learning. If an e-learning environment is considered a system, student characteristics, which are inputs from this system, greatly affect the outcome of the system. Elearning readiness is one of the integral inputs in this system [14]. In the literature, there are various studies on the influence of different learning environments on learning outcomes. In the study, cognitive strategies, motivation and readiness of e-learning were used as characteristics of learners [14].

The design of effective e-learning courses should be developed taking into account student characteristics to produce better learning outcomes [18]. Dabbagh [19] mentions some characteristics and skills that are considered important for the success of e-learning, namely having a strong academic selfconcept, showing fluency in using online learning technology, having interpersonal and communication skills, understanding and appreciating collaborative interaction and learning, having an internal control lofly, showing self-learning skills, and showing the need to be affiliated. Meanwhile, Golladay, Prybutok, and Huff [30] mentioned that some factors of online student success include time commitment, motivation and discipline, having technological skills, having reading skills and process understanding, sharing ideas and experiences, time management skills, having writing skills, reporting problems immediately, meeting 
learning qualifications, trusting online learning, the ability to apply critical thinking. The COVID-19 pandemic demands an institutionally implemented quality assurance system to e-learning becomes even more important, so that students get a quality online learning experience supported by institutions that have competent processes and resources [31].

\section{CONCLUSION}

Online learning is carried out as one of the efforts to prevent the transmission of the COVID-19 virus. In addition to providing many benefits, online learning using e-learning also has many weaknesses that cause dissatisfaction among students. The changing learning system that occurred requires the readiness of lecturers, students, and campuses to face this online learning. The difficulties and problems experienced by students related to the use of e-learning cause student dissatisfaction with this learning system. This difficulty is due to independent learning patterns that students inevitably have to face, support from classmates, interaction and flexibility among colleagues and lecturers and other things that become obstacles in the implementation of e-learning.

The results showed that there are several factors that need to be improved, such as materials presented in e-learning, interaction with lecturers, availability of facilities, and lecturers. Factors that must be maintained include flexibility, assessment in e-learning that is felt to be appropriate, the benefits of elearning, and students' ability to allocate time. Meanwhile, factors that are considered less important and do not obtain priorities include peers, easy-to-understand materials, ability to learn independently and understand tasks. In addition, students consider there are several factors that are considered too excessive, namely self-motivation, ability to understand the use of e-learning, independent learning process. Future research is expected to be done on student characteristics in using e-learning, such as self-efficacy, motivation, locus of control which will further increase satisfaction in using e-learning.

\section{REFERENCES}

[1] L. Rodriguez-Segura, M. A. Zamora-Antuñano, J. Rodríguez-Reséndiz, W. J. Paredes-García, J. A. AltamiranoCorro, and M. Á. Cruz-Pérez, "Teaching challenges in COVID-19 scenery: Teams platform-based student satisfaction approach," Sustain., vol. 12, no. 18, pp. 1-29, 2020, doi: 10.3390/su12187514.

[2] W. Bhuasiri, O. Xaymoungkhoun, H. Zo, J. J. Rho, and A. P. Ciganek, "Critical success factors for e-learning in developing countries: A comparative analysis between ICT experts and faculty," Comput. Educ., vol. 58, no. 2, pp. 843-855, 2012, doi: 10.1016/j.compedu.2011.10.010.

[3] J. E. Luaran, N. N. Samsuri, F. A. Nadzri, and K. B. M. Rom, "A Study on the Student's Perspective on the Effectiveness of Using e-learning," Procedia - Soc. Behav. Sci., vol. 123, pp. 139-144, 2014, doi: 10.1016/j.sbspro.2014.01.1407.

[4] T. H. Wang, "Developing an assessment-centered e-Learning system for improving student learning effectiveness," Comput. Educ., vol. 73, pp. 189-203, 2014, doi: 10.1016/j.compedu.2013.12.002.

[5] A. K. Agariya and D. Singh, "E-Learning quality: Scale development and validation in Indian context," Knowl. Manag. E-Learning, vol. 4, no. 4, pp. 500-517, 2012, doi: 10.34105/j.kmel.2012.04.036.

[6] T. Teo, "A structural equation modelling of factors influencing student teachers' satisfaction with e-learning," $B r$. J. Educ. Technol., vol. 41, no. 6, pp. 150-152, 2010, doi: 10.1111/j.1467-8535.2010.01110.x.

[7] W. S. Chow and S. Shi, "Investigating Students' Satisfaction and Continuance Intention toward E-learning: An Extension of the Expectation - Confirmation Model," Procedia - Soc. Behav. Sci., vol. 141, pp. 1145-1149, 2014, doi: 10.1016/j.sbspro.2014.05.193.

[8] P. C. Sun, R. J. Tsai, G. Finger, Y. Y. Chen, and D. Yeh, "What drives a successful e-Learning? An empirical investigation of the critical factors influencing learner satisfaction," Comput. Educ., vol. 50, no. 4, pp. 1-20, 2007, doi: 10.1016/j.compedu.2006.11.007.

[9] J. S. Mtebe and C. Raphael, "Key factors in learners' satisfaction with the e-learning system at the the University of Dar es Salaam, Tanzania," Australas. J. Educ. Technol., vol. 34, no. 4, pp. 107-122, 2018, doi: 10.1111/j.17471567.2009.00538.x.

[10] C. L. Lin, S. W. Yu, Y. S. Su, F. L. Fu, and Y. T. Lin, "Charismatic learning: Students' satisfaction with e-learning in higher education," J. Internet Technol., vol. 20, no. 5, pp. 1665-1672, 2019, doi: 10.3966/160792642019092005030.

[11] S. Naidu, E-Learning A Guidebook of Principles, Procedures and Practices, 2nd ed. New Delhi: Commonwealth Educational Media Center for Asia, 2003.

[12] W. M. Al-rahmi, M. S. Othman, and L. M. Yusuf, "Exploring the Factors that Affect Student Satisfaction through Using E-Learning in Malaysian Higher Education Institutions," Mediterr. J. Soc. Sci., vol. 6, no. 4, pp. 299-310, 2015, doi: 10.5901/mjss.2015.v6n4s1p299.

[13] M. Corry and J. Stella, "Teacher self-efficacy in online education: A review of the literature," Res. Learn. Technol., vol. 26, pp. 1-12, 2018, doi: 10.25304/rlt.v26.2047. 
[14] S. Keskin and H. Yurdugül, "Factors Affecting Students' Preferences for Online and Blended Learning: Motivational Vs. Cognitive," Eur. J. Open, Distance E-Learning, vol. 22, no. 2, pp. 72-86, 2019, doi: 10.2478/eurodl-2019-0011.

[15] O. O. Jethro, A. M. Grace, and A. K. Thomas, "E-Learning and Its Effects on Teaching and Learning in a Global Age," Int. J. Acad. Res. Bus. Soc. Sci., vol. 2, no. 1, pp. 203-210, 2012.

[16] M. L. Cheok and S. L. Wong, "Predictors of E-learning satisfaction in teaching and learning for school teachers: A literature review," Int. J. Instr., vol. 8, no. 1, pp. 75-90, 2015, doi: 10.12973/iji.2015.816a.

[17] N. A. Buzzetto-More, "Student Perceptions of Various E-Learning Components," Interdiscip. J. e-Learning Learn. Objects, vol. 4, pp. 113-135, 2008, doi: 10.28945/370.

[18] M. Thanji and S. Vasantha, "A Study of benefits and limitations of e-learning - A learner's perspective," Int. J. Pure Appl. Math., vol. 118, no. 5, pp. 175-184, 2018.

[19] N. Dabbagh, "The Online Learner: Characteristics and Pedagogical Implications," Contemp. Issues Technol. Teach. Educ., vol. 7, no. 3, pp. 217-226, 2007, doi: 10.1007/springerreference_302098.

[20] J. A. Martilla and J. C. James, "Importance-Performance Analysis," J. Mark., vol. 41, no. 1, pp. 77-79, 1977.

[21] C. Wright and M. O'Neill, "Service quality evaluation in the higher education sector: An empirical investigation of students' perceptions,” High. Educ. Res. Dev., vol. 21, no. 1, pp. 23-39, 2002, doi: 10.1080/07294360220124639.

[22] J. Ziegler, P. Dearden, and R. Rollins, "But are tourists satisfied? Importance-performance analysis of the whale shark tourism industry on Isla Holbox, Mexico," Tour. Manag., vol. 33, pp. 692-701, 2012, doi: 10.1016/j.tourman.2011.08.004.

[23] E. Vieira, J. J. Ferreira, and R. São João, "Creation of value for business from the importance-performance analysis: the case of health clubs," Meas. Bus. Excell., vol. 23, no. 2, pp. 199-215, 2019, doi: 10.1108/mbe-092018-0076.

[24] J. Abalo, J. Varela, and V. Manzano, "Importance values for Importance-Performance Analysis: A formula for spreading out values derived from preference rankings," J. Bus. Res., vol. 60, no. 2, pp. 115-121, 2007, doi: 10.1016/j.jbusres.2006.10.009.

[25] T. Anderson, The theory and practice of online learning, 5th ed. AU Press, 2011.

[26] K. Syauqi, S. Munadi, and M. B. Triyono, "Students' perceptions toward vocational education on online learning during the COVID-19 pandemic," Int. J. Eval. Res. Educ. (IJERE), vol. 9, no. 4, pp. 881-886, 2020, doi: 10.11591/ijere.v9i4.20766.

[27] B. A. Al-Alak and I. A. M. Alnawas, "Measuring the acceptance and adoption of e-learning by academic staff," Knowl. Manag. E-Learning An Int. J., vol. 3, no. 2, pp. 201-221, 2011, doi: 10.34105/j.kmel.2011.03.016.

[28] D. Thurber and L. Trautvetter, "Examining student reported interaction and satisfaction in higher education administration graduate seminar-style blended courses," Online Learn. J., vol. 24, no. 3, pp. 184-202, 2020, doi: 10.24059/olj.v24i3.2102.

[29] P. Ramkissoon, L. J. Belle, and T. Bhurosy, "Perceptions and experiences of students on the use of interactive online learning technologies in Mauritius," Int. J. Eval. Res. Educ. (IJERE), vol. 9, no. 4, pp. 833-839, 2020, doi: 10.11591/ijere.v9i4.20692.

[30] R. M. Golladay, V. R. Prybutok, and R. A. Huff, "Critical success factors for the online learner," J. Comput. Inf. Syst., vol. 40, no. 4, pp. 69-71, 2000, doi: 10.1080/08874417.2000.11647468.

[31] W. Zimmerman, B. Altman, B. Simunich, K. Shattuck, and B. Burch, "Evaluating online course quality: A study on implementation of course quality standards," Online Learn. J., vol. 24, no. 4, pp. 147-163, 2020, doi: 10.24059/olj.v24i4.2325. 